\title{
Are there really new clothes in the NHS wardrobe?
}

\author{
D.P. Forster
}

\begin{abstract}
Much of psychiatric practice involves understanding a patient's perception of reality and the influences that may affect this perception, including those of the environment. In organisations, such as the National Health Service, the need for consensus and approval within the organisational culture and environment may iniluence the publicly expressed views of employees, a process encouraged by short-term contracts and performance related pay. This article briefly describes some diverse experiences relevant to Interpreting the real and the apparent.
\end{abstract}

One of the first books given to me by my parents was a compilation of Hans Christian Andersen's fairy tales. The favourite story for me was always The Emperor's New Clothes. My delight in this story was based on the disbelief that adults could really be so gullible, especially when they had witnessed the intense activity of the weavers on what was clearly to a child's eye, imaginary cloth; and the child in the story was so obviously right.

It was some 20 years later before I became aware of the scientific explanations of the aberrant beliefs expressed in Andersen's story. During the psychology course of my psychiatric training it was revealed how the beliefs and attitudes of individuals could be moulded. The controlled social psychological experiments of the 1950 s began to unravel the important factors in this process, for example, how the power of pressures to conform could be mediated through an individual's need for social approval and consensus in a group. Among the most cogent studies were those of Asch which involved groups of subjects making judgements publically about the length of lines (Asch, 1952). In each group, only one person was a genuine subject in the experiment, the others having been coached by the experimenter to give similar erroneous opinions concerning the length of the line. Under these conditions, only about $25 \%$ of the genuine subjects were always correct in their judgement of the length of the lines compared with 95\% in the control situation, when the other subjects colluding with the experimenter expressed the correct answers.

Among much other theoretical and experimental work by American behavioural scientists of the same period, that of Festinger on cognitive dissonance stands out (Festinger, 1957). Festinger argued that individuals strive for consistency in their beliefs, attitudes and behaviour and, when inconsistency or dissonance occurs, it is unpleasant or psychologically uncomfortable. Individuals, therefore, seek to reduce or dispel such conflicts or tensions. The classical example is the smoker who knows of the link between lung cancer and the smoking habit. Reduction of dissonance can occur through either a change in behaviour by stopping smoking; devaluing the evidence; or reassuring oneself about the perceived positive aspects of enjoyment and relaxation through continued smoking. Personal commitment to a decision or action is known to enhance the need to reduce dissonant perceptions.

A later experience, among many, of trying to distinguish the real from the apparent occurred in the mid-1980s. I was visiting Czechoslovakia as part of a project attempting to determine whether there was greater equality of health status between different social and occupational groups under the eastern European health systems of that time (largely based on the Soviet model) compared with that in western countries. I had heard of an information system in eastern Europe for the quick dissemination of health and health service information. To see if it would be useful for the research project, I visited one of the Information Institutes in Prague.

The Director of the Institute was a cultured man; he spoke perfect English and discussed American and English literature at length. I promised to send him some books which he had found difficult to obtain and then raised the reason for my visit and asked whether the information system could provide relevant data for the study in question. He explained that the information system had not been a success and described it as a 'Potemkin village'. He patiently recounted the story of Prince Grigory Potemkin, a favourite of Catherine II in 18th century Tzarist Russia. Potemkin was a powerful, ambitious soldier and administrator who was made governor of southern Ukraine by Catherine. Although he achieved much, he was inclined to 
exaggerate his enterprise and, prior to a visit by Catherine to assess the situation in the Ukraine, is alleged to have erected the facades of artificial villages which would be noticed by her. The term 'Potemkin village' thus became synonymous with attempts to hide the true state of affairs.

The Director ruefully pointed out that the information system in question was indeed for the sake of appearance in the political milieu in which he worked and that it did not produce data of value. At that time, several years before the 'velvet' revolution in Czechoslovakia, I had two possible interpretations of this experience. The first and intuitive perception was that a brave man, working in an oppressive system had, in spite of the pressures for conformity, told me of his personal, real belief about this particular information system. The second was that I was being informed 'politely' that I couldn't have the data from this system for the research study. Subsequent events, following the liberalisation of eastern Europe, have confirmed the former view.

These brief reflections on literature, experience and science with respect to the real and the apparent were prompted by a recent advertisement for the post of Head of Public Affairs in a NHS trust in the south of England. The major objective of the advertised job was 'to help us (the top management of the trust) manage what the public eye sees'. This is not encouraging for a public interested in learning about matters of genuine public concern. particularly when it is known that NHS management and policy makers have, at best, an equivocal attitude to whistle blowing, for which the law offers little protection (Greene \& Cooper, 1992; Smith, 1992). Moreover, these constraints are amplified by a health system moving rapidly towards short-term contracts, performance related pay; and in which all chairpersons of health authorities and trusts are appointed by the Secretary of State. No longer is it a requirement to seek local authority nominees and the conditions exist, at least in potential, for health authorities and trusts to be filled with persons holding acceptable views.

How, therefore, can we determine what is really happening in the NHS, given these inherent influences for conformity in NHS employees? For fields in which relevant, objective and unbiased information may be accrued, independent research may provide some of the answers. It is, however, heartening, in a general climate of uncertainty concerning openness, that the NHS Research and Development Strategy, in its guidance for RHAs, has specified that "there should be free flow of information about the findings of research under the strategy" (NHS Management Executive, 1991). This is particularly important in a field increasingly dominated by commissioned research. Let us hope, therefore, that the Regional Research and Development Committees have the courage to support independent studies which may address awkward questions concerning the success or otherwise of the changed NHS.

\section{References}

ASCH, S.E. (1952) Effects of group pressure on the modifcation of and distortion of judgements. In Groups, Leadership and Men (ed. Guetzkow). Pittsburgh: Carnegie.

Festinger, L. (1957) A Theory of Cognitive Dissonance. Stanford: Stanford University Press.

GREENE, D. \& COOPER. J. (1992) Whistle blowers. British Medical Journal, 306, 1343-1344.

NHS MANAGEMENT EXEcuTrve (1991) NHS Research and Development Strategy: guidance for regions.

SMrr, R. (1992) Whistle blowing. British Medical Journal. 305, 1308-1309.

D.P. Forster, Senior Lecturer, School of Health Care Sciences, The Medical School, Untverstty of Newcastle upon Tyne, Newcastle upon Tyne NE2 4HH 